\title{
AFTER RIO+20: PREPARING FOR SUSTAINABLE RETREAT?
}

\author{
PAVEL NovÁČEK \\ Department of Development Studies, Palacky University, Olomouc, the Czech Republic
}

Manuscript received: August 12, 2012

Revised version: February 17, 2013

NovÁčEK P., 2013. After Rio+20: Preparing for Sustainable Retreat? Quaestiones Geographicae 32(1), Bogucki Wydawnictwo Naukowe, Poznań, pp. 55-60. DOI 10.2478/quageo-2013-0007, ISSN 0137-477X.

\begin{abstract}
The industrial age has brought us much good: a higher quality of life which is reflected in better healthcare and education, a longer life expectancy etc. But besides the indisputable benefits, the industrial age has also caused many problems which are now assuming global proportions. In 1987 UN Commission on Environment and Development attempted to propose how to enable people and whole nations to develop while sustaining functioning ecosystems and healthy environment. The key term became "sustainable development". But problem with sustainable development concept is that it is so vague and "all-embracing". Its biggest deficiency is the fact that it fails to attempt to even define human needs. The United Nations Conference on Sustainable Development (Rio+20 conference, June 2012) did not change current unsustainable development trends. Therefore we should allow for and ponder the possibility that effort at sustainable development will fail and the human community will experience great civilization turbulence. Maybe it is too late for sustainable development, what we need is a sustainable retreat. Our abilities are limited and promoting sustainable development may prove to be beyond us. In comparison with our ancestors we have much greater opportunities. But this has not been counterbalanced by greater responsibility and foresight. We should explore and study future opportunities and dangers that could occur under certain conditions. These images of possible futures may help to make our present decisions more qualified and responsible.
\end{abstract}

KEY wORDS: sustainable development, sustainable retreat, zero growth, Rio Summit, World Summit, Rio+20 Summit

Pavel Nováček, Department of Development Studies, Palacky University, Olomouc, tř́da 17. listopadu 12, 77146 Olomouc, the Czech Republic, e-mail: pavel.novacek@upol.cz

\section{Introduction}

That's one small step for a man, one giant leap for mankind - these were the words of Neil Armstrong, the first person to set foot on the Moon on July 21, 1969. It was a triumph of human hope, will, and creativity in the best possible sense. The Apollo 11 flight and the landing of a human on an extraterrestrial body should remind us that once people have a vision and the will to imple- ment it, they are capable of great things. Today we are also in need of a daring vision of what to do next. Perhaps even more importantly, we need sufficient will to continually promote this meaningful vision.

Forty years ago we managed to send people to the Moon yet we remain unable to prevent people from dying of hunger. In many regions the environment is damaged or being destroyed. Many animal and plant species are irretrievably disappearing due to human activities. The 
world's population continues to grow, increasing the antropogenic pressure on the ecosystems and natural resources.

\section{Limits to Growth and Sustainable Development}

The industrial age has brought us much good; better material security, a higher quality of life which is also reflected in better healthcare and education, a longer life expectancy, etc. But everything has its pros and cons. Besides the indisputable benefits, the industrial age has also caused many problems which are now assuming global proportions and, at the level of individual states, are difficult or even impossible to solve. The global problems of the human community have been subject to intensive research since the 1970s.

Interest in global problems was significantly influenced by the oil crisis of 1973. At the time many existing problems were escalating, becoming more obvious and visible. Very pessimistic works were published, such as the first report to the Club of Rome The Limits to Growth (Meadows et al. 1972), proposing zero growth as the only possibility for the future development of the world.

Reports to the Club of Rome and some other globally oriented reports of the 1970 and early 1980s demonstrated that the exponential growth in production and consumption within the restricted Earth ecosystem is not sustainable in the long term. ${ }^{1}$ It was also more and more obvious that is was necessary to respect the different views held by developed and developing countries, as the developing countries were justly ex-

The reports involved the first report to the Club of Rome The Limits to Growth (1972) as well as some of the other reports: Mankind at the Turning Point (Mesarovic \& Pestel 1976), Reshaping the International Order (Tinbergen 1976), Beyond the Age of Waste (Gabor \& Colombo 1978), Goals for Mankind (Laszlo E. \& Club of Rome 1977), No Limits to Learning (Botkin et al. 1978), Road Maps to the Future (Hawrylyshyn 1980). Apart from activities of the Club of Rome and its associates, other publications included e.g. To Have or To Be by Fromm (1976), The Turning Point by Capra (1982), Small is Beautiful by Schumacher (1973), Gaia: A New Look at Life on Earth by Lovelock (1979), The Global 2000 Report to the President by Barney (1980) and others. pressing their wish to establish first better living conditions and only then perhaps adopt restrictions in respect of the ecosystem' sustainable capacity.

Therefore in 1983 the UN Secretary-General Javier Perez de Cuellar invited the Prime Minister of Norway, Gro Harlem Brundtland, to establish an international commission that would attempt to propose how to enable people and whole nations to develop while sustaining functioning ecosystems and a healthy environment. The efforts of the World Commission on Environment and Development over the course of four years resulted in a report called Our Common Future, published in 1987. The key term of probably the most important UN report of the 1980s was sustainable development.

According to the United Nation World Commission on Environment and Development (UNWCED 1987), sustainable development is development that meets the needs of the present without compromising the ability of future generations to meet their own needs. In its broadest sense, the strategy for sustainable development aims to promote harmony among human beings and between humanity and nature. The above definition is so vague and "all-embracing" that it is impossible not to agree with. Its biggest deficiency is the fact that it fails to attempt to even define human needs. Daly (1996) pointed out that in the second half of the 1990s the vagueness of the concept of sustainable development ceased to serve as a consensus platform and instead became a source of controversy.

\section{From Rio to Rio+20 Summit}

In June 3-14, 1992, five years after the World Commission on Environment and Development (the Brundtland Commission) published its report Our Common Future, the then largest conference in history was held in Rio de Janeiro ${ }^{2}$, with a view to elaborating the vision of sustainable development and encouraging its gradual fulfillment at the international, national, and local levels. Officially titled The United Nations Conference on Environment and Development (UNCED),

2 Online: http://www.un.org/geninfo/bp/enviro.html, February 13, 2013. 
the event was attended by 178 countries. The extremely demanding negotiations resulted in the following five documents:

1. Rio Declaration on Environment and Development,

2. United Nations Framework Convention on Climate Change,

3. Convention on Biological Diversity,

4. Agenda 21,

5. Non-Legally Binding Authoritative Statement of Principles for a Global Consensus on the Management, Conservation and Sustainable Development of All Types of Forests.

The initial ambitions of the Rio Summit are best expressed in a statement made by Gro Harlem Brundtland: We are compelled to manage the most important global transformation since the agricultural and industrial revolutions - the transition to sustainable development. The countries of the former socialist bloc were legitimately classified as developed. However, they failed to act in a coordinated way. The developing countries did not trust them, fearing the Eastern bloc would drain away some of the development aid. ${ }^{3}$

The World Summit on Sustainable Development (WSSD) took place in Johannesburg ${ }^{4}$, South Africa, from August 26 to September 4, 2002. It was attended by 21 thousand accredited delegates from 191 countries. Politicians and diplomats may say a hundred times it was a moderate success but they can hardly deny that the accomplishments were quite trivial. The World Summit on Sustainable Development was held following a resolution of the $55^{\text {th }}$ session of the UN General Assembly in December 2000, with a view to assessing the ten-year implementation of the UN Conference on Environment and Development held in Rio. The summit itself suffered mainly due to the unwillingness of the part of the main actors of International politics to adopt new commitments beyond the scope of the agreements

To a certain extent, this fear came true. In the early 1990s, total development aid dropped globally from USD 65 billion a year to USD 55 billion. However, in the first half of the first decade of the $21^{\text {st }}$ century, the total aid grew to more than USD 100 billion, and a number of former socialist countries (namely Central European countries and the Baltic states of the former Soviet Union) began donating development aid.

4 Online: http://www.johannesburgsummit.org/, February 13,2013. made in Rio. The negotiations were conducted along three principal parallel lines:

1. Thematic plenary discussions on the problems of water, energy, health, agriculture, biodiversity (WEHAB),

2. Negotiation of the two fundamental outputs of the Summit - the Johannesburg Declaration on Sustainable Development and the Plan of Implementation,

3. Presentation of partnership initiatives - voluntary activities supporting the realization of objectives assumed in the Plan of Implementation.

The Summit naturally paid extraordinary attention to Africa and sub-Saharan Africa in particular. The New Partnership for Africa's Development (NEPAD) was approved, aiming to bring a new impulse to the development of Africa. Today, ten years later, we can say that the results of NEPAD have been dismal. To a great extent, the activities depend on the funding provided by developed countries, and there has been no important project worthy of being labeled a success story.

Within "partnership initiatives", the UN Commission on Sustainable Development secretariat received over 500 proposals, of which 255 were accepted. At the time of the Summit, only approximately $64 \%$ of the initiatives were financially covered and, in total, not more than US \$ 252 million was available for their implementation. This number appears dismal especially when compared with the then estimate of the financial amount that would be required to ensure sustainable development on the global scale - US \$ 625 billion every year. The state sector formed 35\% of the partnership initiatives, while global governmental organizations had 39\% (particularly UNEP and UNDP). The NGOs, scientific and research centers, local authorities, and universities combined had a $26 \%$ share. The participation of the private sector was disappointing - a mere $0.16 \%$ share in the partnership initiatives.

The third big summit, the United Nations Conference on Sustainable Development, so called Rio $+20^{5}$, June 20-22, 2012, is not going to change current unsustainable development and

Online: http://www.uncsd2012.org/, February 13, 2013. 
trends, concerning climate change, water scarcity, over-consumption of natural resources, desertification, severe institutional failures etc. Therefore we should allow for and ponder the possibility that effort at sustainable development will fail (for the lack of determination, time, or both) and the human community will experience great civilization turbulence.

Even if we had the determination and strength to cope with one problem, we do not have time to respond to the others, which in addition function synergically, are inter-supportive, and strenghten one another's effect. Even if some society found the strength and determination to restrain itself and make sacrifices and accept "blood, sweat, and tears" (the way the British did in WWII upon Churchill's appeal), it will not suffice, for an efficient response to global problems would require action from the entire human society. There is not even a hint that we would be capable of this.

\section{Roots of the Crisis}

How is this possible when we have so much information available? How did we get into a situation where, despite all the wonderful possibilities and achievements of science and technology, we, for the first time in history, are confronted with very serious and culminating problems of global extent? I do not aspire to provide and exhaustive response - that is beyond us. It is possible though to mention several ideas which, in my opinion, reasonably precisely convey the causes of our problems.

1. Throughout human history, we have carried the beautiful and at the same time heavy burden of freedom of choice. We are able to do good things but equally we are capable of becoming an evil beast. The genocides of the $20^{\text {th }}$ century should not leave anyone in doubt as to how low humans can sink.

2. Our misleading understanding of progress is rooted in the industrial development of the $19^{\text {th }}$ and $20^{\text {th }}$ centuries. Toffler (1980) claims that our civilization has built its understanding of progress on three ideas which have led us into crisis:

a) It is right to exploit and rule nature. b) People are the supreme creation of evolution, the principle of natural selection (Darwin) is transferred also into social understanding (the richest and most powerful people are also the most able and the most worthy).

c) History irreversibly makes for the better life of humankind.

3. It is remarkable how many people in various periods of time have thought that the reason behind the crisis and decline of the individual and society is that which we often deem as a desirable aim - affluence.

Affluence itself is not bad and, if managed and used well, it can be a blessing. Alas all too often it is accompanied by greed, which is a deadly sin for Christianity, coming second after pride. Even earlier, Gaius Sallustinus Crispus (86-35 BC) observed the bitter fruits of the amassing of wealth: But when the state became powerful through work and justice, powerful kings were overcome in war, barbarous tribes and great nations were subjugated by power, when Carthage, a rival of the Roman Empire, was wiped out to the roots, when all the seas and lands were open to them - at that time luck started to play the devil and to turn everything upside down. For those who had easily borne pains, danger, unsure and difficult periods, peace and wealth, at some other time so desirable, became a burden and bad luck. Affluence also leads to the irresolution and flabbiness of entire nations (and above all their political elites) and to an inability to accept energetic, even if painful measures. Winston Churchill described it brilliantly in 1936, when he criticized the British government for their inability to face the danger of the Nazi Germany: This government is simply not able to make a decision or make the Prime Minister do so. Therefore they continue in this peculiar paradox, decided to be indecisive, resolved to resolve nothing, stubborn in their hesitation, firm in their flabbiness, strong in their powerlessness. ... We are approaching the end of the era of postponements, partial solutions, comforting and nonsensical excuses and delays. Instead we are entering the period of their consequences.

4. British historian, Johnson (1983), offers a rather different, provocative but undoubtedly also inspiring view of the cause of present crisis. 
He considers moral relativism to be our main problem: Marx described a world whose leverage was economic interest, for Freud sexual motivation was the most important. Both assumed that religion, the original impulse which moves individuals and crowds, is and always was a mere fiction. The third of this trio of great German thinkers, who tried in the $19^{\text {th }}$ century to explain human behavior, Friedrich Nietzsche, was an atheist too. ... Religious faith will be replaced by secular ideology. Those who once filled the ranks of totalitarian clergy will become totalitarian politicians. The will to power will give birth to a new kind of messiah who will not be limited by any religious principles and will want to govern Mankind with an inextinguishable desire. The end of the old order and the world lurching without a guide in a relativistic universe was a direct appeal for gangster statesmen to appear on the scene. Their appearance was not long in coming.

\section{From Sustainable Development to Sustainable Retreat}

British physicist Lovelock (1979) formulated more than 30 years ago the Gaia hypothesis: Gaia is a thin spherical shell of matter that surrounds the incandescent interior; it begins where the crustal rocks meet the magma of the Earth's hot interior, about 160 $\mathrm{km}$ below the surface, and proceeds another $160 \mathrm{~km}$ outwards into space. It includes the biosphere and is a dynamic physiological system that has kept our planet fit for life for over three billion years. ... The Gaia hypothesis views the biosphere as an active, adaptive control system able to maintain the Earth in homeostasis (Lovelock 1979). At the age of 86, Lovelock published The Revenge of Gaia (2006). He may be the first well-known author to have crossed the Rubicon ${ }^{6}$, maintaining: It is much too late for sustainable development; what we need is a sustainable retreat. ... The error the supporters of sustainable development and laissez faire of business share is the be-

\footnotetext{
Prior to Lovelock, all the other authors dealing with global problems, starting with Donella and Denis Meadows, claimed: unless we change our behavior, within thirty (twenty, ten) years a catastrophe will strike. Lovelock was the first one to abandon the idea of a "bright future", he believes that we have lost this opportunity.
}

lief that further development is possible, and the Earth will continue, more or less as now, for at least the first half of this century. ... By changing the environment we declared war on Gaia. We violated the environment of other species much the same as if in the affairs of nation states we had invaded territory of other nations.

Retreat, in his view, means that it's time to start talking about changing where we live and how we get our food; about making plans for the migration of millions of people from low-lying regions like Bangladesh into Europe; about admitting that New Orleans is a goner and moving the people to cities better positioned for the future. It's about everybody absolutely doing their utmost to sustain civilization, so that it doesn't degenerate into Dark Ages, with warlords running things, which is a real danger.

Lovelock offers a simile, which former Czechoslovakia in particular and Europe in general should understand as a strong warning: I am old enough to notice a marked similarity between attitudes more than 60 years ago towards the threat of war and those now towards the threat of global heating. Most of us think that something unpleasant may soon hapen, but we are as confused now as we were in 1938 as to what form it will take and what to do about it. ... The Kyoto agreement was uncannily like the Munich pact, with politicians out to show their eagerness to respond while in reality merely playing for time.

We should act upon the ecologists' advice and (among other things) save energy, but it is similar to losing weight - easier said than done. He compares our situation to Napoleon's tragic march on Moscow in 1812, when retreating in time was the most reasonable thing Napoleon could have done. The quality of leadership, according to Lovelock, is measured by the ability to organize a successful retreat. The time has come when all of us must plan a retreat from the unsustainable place that we have now reached.

Despite all our efforts to retreat sustainably, we may be unable to prevent a global decline into a chaotic world ruled by brutal war lords on a devastated Earth. One way of alleviating the consequences of the disaster is to store and transmit the key knowledge that will help our descendants develop civilization again, without repeating our mistakes. For, as Lovelock put it, It is careless to be cavalier about our own death. It is reckless to think of civilization's end in the same way. 
I hope there is still some time to take action to prevent his vision from happening. Our abilities are, none the less, limited and promoting sustainable development may prove to be beyond us.

\section{Conclusion}

In comparison with our ancestors we have much greater opportunities to influence our environment. This has not been, it seems, counterbalanced by greater responsibility and foresight.

Throughout all their history, human beings have learnt from their past experience or the past experience of their fellow humans. This model functioned well for thousands of years, as long as the consequences of our deeds (and errors) were space and time limited. Scientific knowledge and technological development have provided us with such powers that potential errors may now lead to a severe aftermath, whether it concerns e.g. the peaceful or military use of nuclear energy, genetically modified organisms, climate change, etc. Therefore it is necessary to learn not only from the past but also from possible futures.

We can explore and study future opportunities and dangers (or range of possible futures) that could occur under certain conditions. These images of possible futures (desirable as well as undesirable) may help to make our present decisions more qualified and responsible.

The future is not predetermined or set in stone. People have freedom of choice. As the future is not predetermined and we have freedom of choice, it can be influenced by our choices (even if only slightly). As the future can be influenced by the choices we make, it makes sense to study and see the future in all its diversity, from sustainable development scenario through sustainable retreat to coming anarchy and disruption scenario. This applies to individuals as much as to humankind as a whole.

\section{References}

Barney G.O., 1980. The Global 2000 Report to the President. Pergamon Press, Oxford.

Botkin J., Elmandjra M. \& Malitza M., 1978. No Limits to Learning. Pergamon Press, Oxford.

Brown L., 2009. Plan B 4.0 - Mobilizing to Save Civilization. W.W. Norton \& Company, New York.

CAPra F., 1982. The Turning Point: Science, Society, and the Rising Culture. Simon and Schuster, New York.

Daly H.E., 1996. Beyond Growth. Beacon Press, Boston.

Fromm E., 1976. To Have or to Be? Abacus, London.

Gabor D. \& Colombo U., 1978. Beyond the Age of Waste. Pergamon Press, Oxford.

Hawrylyshyn B., 1980. Road Maps to the Future. Towards More Effective Societies. Pergamon Press, Oxford.

Johnson P., 1983. A History of the Modern World from 1917 to the 1980s. Weidenfeld \& Nicholson, London.

LASZlo E. \& CluB OF ROME, 1977. Goals for Mankind: a report to the Club of Rome on the new horizons of global community. Dutton, New York.

Lovelock J., 1979. Gaia: A New Look at Life on Earth. Oxford University Press, Oxford

Lovelock J., 2006. The Revenge of Gaia. Basic Books, New York.

Meadows D.H., Meadows D.L., Randers J. \& Behrens III W.W., 1972. The Limits to Growth. Universe Books, New York.

Mesarovic M. \& Pestel E., 1976. Mankind at the Turning Point. Dutton, New York.

NovÁČEK P., 2011. Sustainable Development. Palacky University Press, Olomouc.

Schumacher E.F., 1973. Small is Beautiful. A Study of Economics as if People Mattered. Blond and Briggs, London.

TinBergen J., 1976. RIO Report: Reshaping the International Order. Dutton, New York.

Toffler A., 1980. The Third Wave. Bantam Books, New York.

UNWCED [United Nations World Commission on Environment and Development], 1978. Our Common Future. Oxford University Press, Oxford. 